International Journal of Instruction e-ISSN: 1308-1470 • www.e-iji.net

Article submission code: 20201124155732

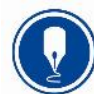

October $2021 \bullet$ Vol.14, No.4

p-ISSN: 1694-609X

pp. $841-856$

Received: 24/11/2020

Revision: 30/04/2021
Accepted: 24/05/2021

OnlineFirst: 02/09/2021

\title{
The Increasing of Math Adversity Quotient in Mathematics Cooperative Learning Through Metacognitive
}

\section{Zubaidah Amir MZ}

Corresponding author, State Islamic University of Riau, Indonesia, zubaidah.amir@uinsuska.ac.id

\section{Risnawati}

State Islamic University of Riau, Indonesia, risnawati@uin-suska.ac.id

\section{Erdawati Nurdin}

State Islamic University of Riau, Indonesia, erdawati.nurdin@uin-suska.ac.id

\section{Memen Permata Azmi}

State Islamic University of Riau, Indonesia, memen.permata.azmi@uin-suska.ac.id

\section{Dedek Andrian}

Dr., Riau Islamic University, Indonesia, dedekandrian@edu.uir.ac.id

\begin{abstract}
Students' success in learning is inseparable from their high level of fighting power or the Adversity Quotient (AQ) they have. This study examines whether there was an Adversity Quotient (AQ) difference between Boarding Schools (BS) and NonBoarding Schools (NBS) students through the application of metacognitive learning Think-aloud cooperative setting through the application of metacognitive learning Think-aloud cooperative setting Think-Pair-Share (MTPS), Think-Pair Square (MTPQ), and Conventional Class (CC). The researchers used quasiexperimental research design. The data collection in this study involves students in 2 schools namely; boarding schools (BS) and non-boarding schools (NBS) system in Pekanbaru. With statistics analysis of ANOVA, it was found that there was a difference of AQ of students to the learning of mathematics in the three groups of learning strategies (MTPS,MTPQ, CC). The strategies that best influence the successive AQ of students are the strategies of MTPS, CC, MTPQ. There was also an interaction effect between learning strategies with the school system on AQ students. Student AQ is higher in the NBS group in BS students. Student AQ indicators are high on control and reach aspects, while other indicators are categorized (origin, ownership, and endurance). This research contributes to the development of the study of metacognitive think-aloud strategy and adversity quotient in mathematics learning.
\end{abstract}

Keywords: adversity quotient, metacognitive, think-aloud, cooperative think-pair-sharesquare, mathematics cooperative learning

Citation: Amir MZ, Z., Risnawati., Nurdin, E., Azmi, M. P., \& Andrian, D. (2021). The increasing of math adversity quotient in mathematics cooperative learning through metacognitive. International Journal of Instruction, 14(4), 841-856. https://doi.org/10.29333/iji.2021.14448a 


\section{INTRODUCTION}

Many factors affect the success of students in learning, including in learning mathematics. The success of learning is the result of the interaction of various factors that influence learning outcomes. Factors in question are factors that exist within students (internal) and external factors from the students (external) (Sardiman, 2012; Ahmadi, Abu, Supriyono, 2004). One of the internal factors that influence the success of learning mathematics is Adversity Quotient (AQ).

Learning is basically overcoming difficulties. Experiencing difficulties, means one is still given the opportunity to hone back the sensitivity of feeling, sharpness of mind, and intelligence (Ronnie in Sudarman, 2012). Overcoming difficulties in other languages is known as Adversity quotient (AQ). AQ is the individual intelligence in overcoming any difficulties that arise (Stoltz, 2004). Thus, students who have a good AQ, will be able to face any learning difficulties (US, Supardi, 2013; Wardiana, et al, 2014).

There are four main dimensions of Adversity quotient (AQ) which form the basis of the measurement of Adversity quotient in students. Dimensions of forming AQ, namely: 1) Control (Control), 2) Origin and Ownership (Possession and recognition), 3) Reach, and 4) Endurance (Stoltz, 2004; Canivel, 2010). Furthermore, the individual with the dimension of control (control), himself always think optimistically, there is always a way, and try to solve the problem (Stoltz, 2004). In other words, Adversity quotients as endurance, power rise and unyielding attitude of someone. AQ is a determining factor in a person's success both academically and non academically (Phoolka, 2012). IQ will determine a person how to deal with difficult conditions, control the situation, formulate problems and solve problems, and be optimistic in solving problems.

Adversity quotient is the will you succeed, your resilience, the ability to bounce back, not be deterred in your quest" (Supardi,2013), ". So someone who has a good Adversity quotient, will be able to deal with any difficulties that exist. On the other hand a person with an adversity quotient who is not good will have great difficulty over the problem he faces (Stolz, 2004).

AQ plays a role in as an individual will face challenges in everyday life, such as competition, productive, learning, and endurance (Matore et al, 2015). This is confirmed by Parvathy et.al (2014: 23), he states "Students face a lot of situations orchallenges in their daily life. "Students who have a high AQ, will be able to survive in facing various difficulties in learning. Students who have high AQ, will try to find solutions as much as possible in solving math problems (Amir et al, 2017). Therefore, AQ is needed by students in facing problems in learning mathematics.

There are three types of AQ, namely: low QQ quitter type), type AQ camper being), and climber type (high AQ) (Isna et al, 2013). Supardi research results (2013) concluded that the higher AQ students, the higher the achievement of learning mathematics, and vice versa. Students with high AQ, difficulty for him just make it a student unyielding. students who are Quitter type always avoid problems in the form of problem solving, lack of enthusiasm in doing the task given (Sudarman, 2011). Therefore, it is necessary to improve students' AQ through learning, one of them is metacognitive learning. 
Metacognitive has been a major topic in the field of cognitive development writing since 1973 (Papaleontiou-Louca, 2003). knowledge and beliefs about cognitive, in addition to possible skills and strategies in self-regulating cognitive processes (Corte ,1996). Metacognitive as a process of cognition, such as one's thinking, thinking about one's thinking, responding to the thoughts of others by monitoring and managing it (Papaleontiou-Louca, 2003). So metacognitive is concerned with thinking about thinking. With the awareness of what is in the mind, it will play a role in aspects of student self-control in learning.

Three categories of metacognition in mathematics learning, namely: beliefs and intuition, knowledge of thought processes, and self-awareness or self-regulation (Schoenfeld, 1987). Having this category of beliefs and intuitions means that the student is trying to have the confidence that he or she can solve the problem. Knowledge of the thinking process is concerned with how accurately one can describe its thinking. Schoenfeld (1987) suggests that this awareness or self-regulation can be considered using a management approach that includes the following aspects: 1) assessing an understanding of the problem as a whole; 2) plan the settlement strategy; 3) monitor and control the ways in which the settlement works; 4) allocate the results, decide what to do and how long the problem is solved. Thus the metacognitive learning characteristics that students can assess the overall understanding of the problem, are able to plan the settlement strategy, can monitor and control the ways of completion running, and can allocate the results, decide what to do and how long the problem is solved, this is in accordance with the AQ indicator of control, endurance, endurance, searching for the origin of the problem and finding solutions to problems (origin) and ownership. So metacognition is very important in developing AQ students.

Yoong (2012) in his research that examines how to help students have metacognition in mathematics, he introduced a way that can be done to help students in self-reflection students. This technique is called a "thinking checklist". These questions include: (a) What ideas and skills have you mastered? (b) What topics are difficult to study? (c) What strategies do you need to find to overcome adversity? (d) What learning activities do you enjoy? The teacher can evaluate the success of students with these questions Yoong further explained that this technique can be done with verbal, at the end of learning / material, "This will make the metacognitive strategies more explicit through verbalisation".

Meanwhile Camp et.al (1977) developed a program to increase self-control called Think-Aloud. There are four questions that the child will use to solve the problem, What was the problem found? what is the strategy for doing it? How to plan this strategy? and How to run optimally? In line with this, Lioe, Fai \& Hedberg (2006) tried to pair (pair problem solving) as a Thinkerand Listener in elementary school students. The results of his research, metacognitive-pair effective in the process of solving mathematical problems. He stated that "The results suggest that Thinker-Listener approach can be extended on a scale of pairs with longer periods of time to observe the effectiveness in developing students' metacognitive strategies" (Lioe et al., 2006: 1). Thus think-aloud can be set by pair, or with in group setting (cooperative) (Amir MZ et al, 2016). 
Based on the Amir MZ (2017) study, the metacognitive strategy most rarely used by MTs students (BS and NBS School) is think-aloud. Amir et al further explained that the metacognitive strategy most often used by teachers is cooperative learning. Research results Amir MZ and Wahyudin (2016) suggested that Think-aloud metacognitive to be tested in high school and high school students. Based on the above suggested research, the author tries to integrate think-aloud in cooperative settings, such as Think-Pair-Share or Square.

Metacognitive skills can be developed in cooperative learning (Abdurrahman, 1999). Furthermore, he explained because in cooperative learning communication occurs among group members. The condition of cooperative learning should include that the group consists of 2-6 members, the positive dependence of each other, the interaction and group communication in terms of way, example and verbal, have responsibility the same to advance their group (Leikin et.al, 1999).

This TPS learning also gives every learner the opportunity to think, answer and help each other his group members. This is a four-step discussion strategy which incorporates wait time and aspects of cooperative learning (Tint \& Nyut, 2015). Group members think about a question / topic individually, and then share their thoughts with a partner. Large group summarized sharing also occur. "Think (Think), Teacher gives assignment to every student then give time to student to think and do the task. Pair (Pair), students are paired with one of the partners in the group and discuss with their partner. Share (sharing), each pair share with all students in class. Cooperative learning Think-PairSquare, has the same stages as above. The difference is only in the Square stage. this stage the two couples meet again in the group of four. Lie explained that in this stage the students have the opportunity to share their work four and re-think in groups.

This study also examines the comparison of AQ students in learning mathematics using direct instruction (Direct Instruction). Direct istruction is an approach to teaching in which lessons are goal-oriented and structured by the teacher (Kadir and Nur, 2000). Direct learning is a teaching approach where learning is goal-oriented (learning) and structured by the teacher. Direct instruction is used to convey the learning that is transformed directly by the teacher to the students (Trianto (2007). This learning is often used by teachers in the classroom, which is often called conventional learning.

Non Boarding School (NBS) and boarding schools (BS) have similarities in the general curriculum, ie there are subjects of mathematics. But of course have the characteristics of different systems. Students in both schools face different situations, so they will respond differently. Students in the dormitory have very tight schedule and duty routines with very strict rules, so it requires students to manage their time and learning strategies well (Zakiyah et al, 2010). Therefore, this study also examines the different AQ responses between students of Non Boarding School (NBS) and boarding school (BS).

From the preliminary above, the researchers formulated this study aims to examine the presence or absence of difference (AQ) of high school students on boarding school (BS) and non boarding school (NBS) system of mathematics learning after applied metacognition learning Think-aloud cooperative setting Think-Pair -Share / Square 
(MTPS), (MTPQ), and Conventional Class (CC). This study also examines strategies that provide better influence, and the dominant indicator in AQ students towards mathematics learning.

\section{METHOD}

The researchers used quasi-experimental research design on students of Madrasah Tsanawiyah in Pekanbaru, Riau, Indonesia. The sample consists of 2 categories of schools namely; boarding school (BS) and non-boarding school (NBS), which amounts to 180 students. Each school consists of three classes with different learning strategies, ie Think-Pair-Share Think-Pair-Share Think-aloud cooperative metacognitive learning (MTPS), Think-Pair-Square cooperative metacognitive learning Think-Pair-Square (MTPQ) metrics, and Conventional Class (CC). The selection of the control class and treatment class was carried out through a purposive sampling approach by examining the abilities of students from each class. In this context, the researcher ensures that all classes have the same abilities as evidenced by the test result was give before learned material. From test results before given material, the obtained information that students are unique, the student has a tiered academic ability (high, medium, and low) and communication activation patterns vary (active, medium, and passive).

In the process of learning in the classroom treatment, students are grouped with heterogeneous academic ability, including the pattern of communication activeness. This is done because it uses a think-aloud strategy that requires students to venture in the verbalization that is in mind in the process of solving math problems. The research design can be seen in Table 1 below:

Table 1

Research design

\begin{tabular}{lllll}
\hline & & \multicolumn{3}{l}{ Students' Adversity Quotient } \\
& & Toward Mathematics Learning \\
\cline { 3 - 4 } & & MTPS & MTPQ & CC \\
& & Strategy & Strategy & Strategy \\
\hline School & MTc Non Boarding School & & \\
\cline { 2 - 5 } System & MTs Boading School/ Pondok Pesantren & \\
& (PP) & & & \\
\hline
\end{tabular}

Data were collected through the AQ scaling post-treatment learning strategy, and supported by interviews on some students. Interviews to students were randomly assigned to students of high, moderate, and low ability and represented both school systems. Interviews conducted in the room specifically to make students feel enjoy and do not feel any intervention in providing data. The scale is developed based on the AQ indicator by Stolz (2004), namely: 1) Control, 2) Origin and Ownership, 3) Reach, and 4) Endurance. The grouping of AQ students consists of five groups: Quitter (very low, low), Champer (medium), and Climber (high, very high). The AQ scale indicator is listed in table 2 below:

Table 2

Scale indicator of adversity quotient 


\begin{tabular}{|c|c|c|c|}
\hline Variable & Dimension & Sub Aspect & Indicator \\
\hline \multirow{7}{*}{$\begin{array}{l}\text { Adversity Quotient } \\
\text { (AQ is defined as } \\
\text { one's intelligence in } \\
\text { the face of obstacles } \\
\text { or difficulties) }\end{array}$} & \multirow{2}{*}{$\begin{array}{l}\text { Control } \\
\text { The student's ability } \\
\text { to control an event is } \\
\text { related to the } \\
\text { difficulties in } \\
\text { mathematics learning } \\
\text { that cause future } \\
\text { difficulties }\end{array}$} & $\begin{array}{l}\text { Understanding that } \\
\text { whatever it is, can be } \\
\text { done }\end{array}$ & $\begin{array}{l}\text { Students respond } \\
\text { positively to a } \\
\text { situation }\end{array}$ \\
\hline & & $\begin{array}{l}\text { How much control } \\
\text { does the student feel } \\
\text { about an event that } \\
\text { causes trouble }\end{array}$ & $\begin{array}{l}\text { Students have strong } \\
\text { control over the } \\
\text { difficulties } \\
\text { experienced }\end{array}$ \\
\hline & $\begin{array}{l}\text { Origin } \\
\text { The ability of } \\
\text { students to examine } \\
\text { the origin of the } \\
\text { causes of difficulty or } \\
\text { failure in learning } \\
\text { mathematics }\end{array}$ & $\begin{array}{l}\text { Who or what is the } \\
\text { origin of difficulty }\end{array}$ & $\begin{array}{l}\text { Students consider the } \\
\text { sources of difficulty } \\
\text { to originate from } \\
\text { others or from outside } \\
\text { and placing their } \\
\text { roles appropriately }\end{array}$ \\
\hline & \multirow{2}{*}{$\begin{array}{l}\text { Ownership } \\
\text { The ability of } \\
\text { students to } \\
\text { acknowledge } \\
\text { themselves as the } \\
\text { cause of adversity, } \\
\text { and to be sure can } \\
\text { definitely improve the } \\
\text { situation. }\end{array}$} & $\begin{array}{l}\text { To what extent do } \\
\text { students acknowledge } \\
\text { the consequences of } \\
\text { the difficulty }\end{array}$ & $\begin{array}{l}\text { Students are able to } \\
\text { judge what they are } \\
\text { doing right or wrong }\end{array}$ \\
\hline & & & $\begin{array}{l}\text { Students are able to } \\
\text { learn for mistakes } \\
\text { made as a result of } \\
\text { difficulties } \\
\text { encountered and fix } \\
\text { them }\end{array}$ \\
\hline & $\begin{array}{l}\text { Reach } \\
\text { The ability of } \\
\text { students to assess a } \\
\text { problem in } \\
\text { mathematics learning, } \\
\text { that the problem will } \\
\text { not interfere with } \\
\text { other activities. }\end{array}$ & $\begin{array}{l}\text { The extent to which } \\
\text { difficulties will reach } \\
\text { other parts of his life }\end{array}$ & $\begin{array}{l}\text { The student limits the } \\
\text { scope of his problem } \\
\text { to the event he is } \\
\text { facing }\end{array}$ \\
\hline & $\begin{array}{l}\text { Endurance } \\
\text { The ability of } \\
\text { students to be } \\
\text { optimistic in facing } \\
\text { various difficulties in } \\
\text { learning mathematics }\end{array}$ & $\begin{array}{l}\text { How long the } \\
\text { difficulty and causes } \\
\text { of adversity will take } \\
\text { place }\end{array}$ & $\begin{array}{l}\text { Students perceive that } \\
\text { the difficulties and } \\
\text { causes of difficulties } \\
\text { encountered are } \\
\text { temporary }\end{array}$ \\
\hline
\end{tabular}

Because the design of this study had more than two sample groups, the AQ response post data was analyzed by inferential statistics, a two-way ANOVA difference test with the help of SPSS version 17 as some previous studies.

\section{FINDINGS}

\section{AQ Difference Test Based on Learning Strategy}


To investigate whether there were differences in AQ of students after different treatment of MTPS, MTPQ, and CC strategies, the data were analyzed using one-way ANOVA test with the hypothesis of the study as follows: There is no difference between AQ students and mathematics as the effect the main implementation of learning strategies MTPS, MTPQ, and CC.

Testing Criteria: if the significant value (Sig.) is less than 0.05 then the hypothesis is rejected. The calculation results are presented in Table 3 .

Table 3

ANOVA test of students' AQ toward learning strategy

\begin{tabular}{lllllll}
\hline & $\begin{array}{l}\text { Sum of } \\
\text { Squares }\end{array}$ & df & $\begin{array}{l}\text { Mean } \\
\text { Square }\end{array}$ & F & Sig. & Hypothesis \\
\hline Between Groups & 7523,79 & 2 & 3761,89 & 24,13 & 0,000 & Rejected \\
\hline Within Groups & 71257,15 & 457 & 155,92 & & & \\
\hline Total & 78780,94 & 459 & & & & \\
\hline
\end{tabular}

From table 3, obtained a significant value of $\mathrm{F}$ by 0,00 . This means the hypothesis is rejected. The conclusion is that there is a difference between AQ students as the main effect of the application of MTPS, MTPQ, and CC learning strategies. Thus the learning strategy gives influence to the students' AQ's ability to math.

To investigate the strategies that gave the best effect most as the next problem formulation, analyzed from the post test Hoc with the Tukey test. The analysis was conducted to test the hypothesis of the following research formula "AQ students in each learning strategy (MTPS, MTPQ, CC) no one overlap from others". The analysis results are listed in Table 4.

Table 4

Tukey test of students' AQ on learning strategy

(I) Strategy (J) Strategy Mean Difference (I-J) Std. Error Sig. Hypothesis

\begin{tabular}{llllll}
\hline \multirow{2}{*}{ Tukey HSD } & \multirow{2}{*}{ CC } & MTPQ & 0,807164 & 1,377014 & 0,828 Accepted \\
\cline { 2 - 5 } & \multirow{2}{*}{ MTPQ } & MTPS & $-8,531739^{*}$ & 1,457372 & 0,000 Rejected \\
\cline { 2 - 6 } & CC & $-0,807164$ & 1,377014 & 0,828 Accepted \\
\cline { 2 - 5 } & \multirow{2}{*}{ MTPS } & MTPS & $-9,338903^{*}$ & 1,467225 & 0,000 Rejected \\
\cline { 2 - 6 } & MTPQ & $9,531739^{*}$ & 1,457372 & 0,000 Rejected \\
\hline
\end{tabular}

From the Table 4 can be seen that the hypothesis accepted on the CC and MTPQ pair. So it can be concluded AQ students in the same group pairs, or AQ students no higher than the others. However, there is a difference of AQ among students between DI groups and MTPS, among MTPS group students with MTPQ. The difference in mean scores indicates that the highest student AQs to the lowest consecutive are on the MTPS, $\mathrm{CC}$, and MTPQ strategy groups. Thus, for a while, researchers suspect that the strategy that gives the most influence to the development of student AQ is the MTPS learning strategy.

AQ Difference Test and Interaction between Learning Strategy and School System 
To find out more about AQ students as a result of the influence of learning strategy on school system, the following analysis is done by differentiation test based on learning strategy on school system control variables (BS and NBS). It also analyzed the interaction between learning strategy and school system to AQ students. The analysis is done to answer the problem formulation with the research hypothesis as follows: There is no difference of AQ between students who follow the learning of MTPS, MTPQ, and CC based on school system (BS and NBS).

The analysis is used with two way ANOVA factor $2 \times 3$. Testing criterion is if significant value $<0,05$ then hypothesis is rejected. The analysis results are listed in Table 5.

Table 5

ANOVA test - two ways ofstudents' AQ on strategy and system

\begin{tabular}{lllllll}
\hline Source & Quadrate Number & Dk & Quadrate Average & F & Sig. & Hypothesis \\
\hline Strategy & 6805,826 & 2 & 3402,913 & 22,603 & 0,000 & Rejected \\
\hline System & 1912,357 & 1 & 1912,357 & 12,702 & 0,000 & Rejected \\
\hline Strategy * System & 1017,754 & 2 & 508,877 & 3,380 & 0,035 & Rejected \\
\hline
\end{tabular}

a. R Squared = ,132 (Adjusted R Squared =,123)

Based on Table 5 it can be concluded that the Learning Strategy factor has a significant influence on student AQ. It is seen from the significant value for strategy is 0,000 . The factor of the school system also has a significant effect on the student AQ. It is seen from the significant value for Learning system is 0,000 . This means there is a significant difference between AQ students based on the strategy and school system. R square value of 0.123 express the effect of variability of learning strategy and school system in explaining student's AQ is $12.3 \%$. Thus, the two variables have an effect on the AQ of $12.3 \%$ and the rest is influenced by other variables.

To see whether or not the interaction effects between learning strategies and school systems on AQ students were tested by proposing the following hypotheses namely; There is no interaction effect between learning strategies and school systems on AQ students. The test criterion is if significant> 0.05 then the hypothesis is accepted.

Table 3 shows the value of $F$ obtained is 3,380 with significant 0.035 . This means the hypothesis that there is no interaction effect between the strategy and the school system on the student AQ is rejected. This means that there is an interaction between school strategies and systems in AQ. In other words, AQ students because of the effect of using learning strategies depend on the shape of the school system and the student AQ because the effects of the school system depend on the use of learning strategies. The interaction between these two variables is shown in the following plot. 


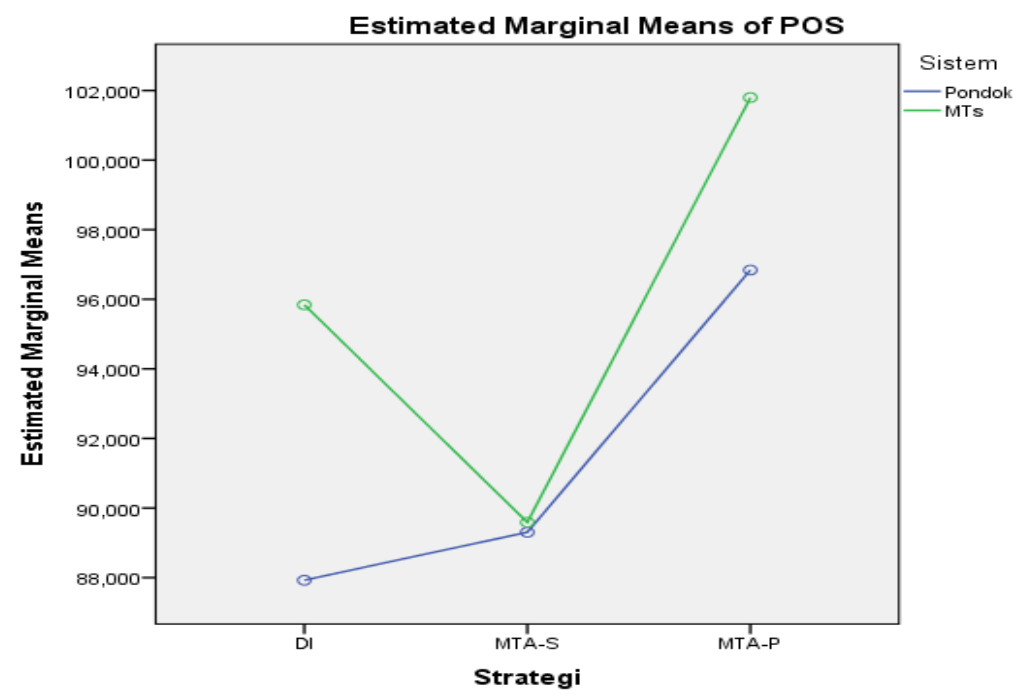

Picture1

Interaction between school strategy and system in AQ

Table 5 provides an explanation that the Learning Strategy and the school system have an influence on AQ. Therefore, for a more in-depth analysis the researcher formulated the following hypothesis namely; the average AQ scores of students in one school system are not higher than the others in each learning. The testing criterion is if the significant value of $\mathrm{t}>0.05$ then the hypothesis is accepted.

To determine whether or not AQ difference in each strategy between school system used $t$ test. The summary of $t$-test results is presented in Table 6 .

Table 6

$\mathrm{t}$-Test of AQ test score based on school system

\begin{tabular}{|c|c|c|c|c|c|}
\hline Strategy & System & Average & $\mathrm{T}$ & sig & Hypothesis \\
\hline \multirow{2}{*}{ Overall } & $\mathrm{BS}$ & 90,73 & \multirow{2}{*}{$-3,887$} & \multirow{2}{*}{0,000} & \multirow{2}{*}{ Rejected } \\
\hline & NBS & 95,74 & & & \\
\hline \multirow{2}{*}{$\mathrm{CC}$} & $\mathrm{BS}$ & 87,92 & \multirow{2}{*}{$-3,392$} & \multirow{2}{*}{0,000} & \multirow{2}{*}{ Rejected } \\
\hline & NBS & 95,84 & & & \\
\hline \multirow{2}{*}{ MTPQ } & $\mathrm{BS}$ & 89,30 & \multirow{2}{*}{$-1,37$} & \multirow{2}{*}{0,891} & \multirow{2}{*}{ Accepted } \\
\hline & NBS & 89,58 & & & \\
\hline \multirow{2}{*}{ MTPS } & $\mathrm{BS}$ & 96,84 & \multirow{2}{*}{$-2,119$} & \multirow{2}{*}{0,036} & \multirow{2}{*}{ Rejected } \\
\hline & NBS & 101,80 & & & \\
\hline
\end{tabular}

From Table 6 can be concluded that both school systems, obtained a significance value of 0.000. This means there is a difference between AQ students. Nevertheless, the analysis continued for each learning strategy of both systems. For MTPS and CC strategies there are significant differences between AQ students of NBS and BS students. However, for the MTPQ learning strategy in both school systems, there is no 
difference in the average AQ of students in the two school systems with a significant value of 0.891 .

\section{Identify AQ students to Mathematics}

Student's (AQ) math competency consists of 5 indicators with a total of 32 statement items. The AQ indicator consists of Control, Origin, Ownership, Reach, Endurance. Here is the percentage data for each indicator in the Table 7.

Table 7

Percentage of AQ indicator recapitulation

\begin{tabular}{lll}
\hline Indicator & $(\%)$ & Category \\
\hline Control & 70.48 & High \\
\hline Origin & 68.63 & Middle \\
\hline Ownership & 68.40 & Middle \\
\hline Reach & 70.64 & High \\
\hline Endurance & 68.28 & Middle \\
\hline
\end{tabular}

From Table 7, the highest AQ indicator is on control and reach / range. While other indicators include the category is. The following percentage of AQ indicators is reviewed from each aspect of each school strategy, system.

Table 8

Distribution of students' AQ category

\begin{tabular}{lllllll}
\hline $\begin{array}{l}\text { Aspect/ } \\
\text { Category }\end{array}$ & Dimension & $\begin{array}{l}\text { Control } \\
(\%)\end{array}$ & $\begin{array}{l}\text { Origin } \\
(\%)\end{array}$ & $\begin{array}{l}\text { Ownership } \\
(\%)\end{array}$ & $\begin{array}{l}\text { Reach } \\
(\%)\end{array}$ & $\begin{array}{l}\text { Endurance } \\
(\%)\end{array}$ \\
\hline \multirow{3}{*}{ Strategy } & CC & 68.73 & 65.94 & 68.18 & 68.86 & 67.24 \\
\cline { 2 - 7 } & MTPQ & 69.35 & 66.46 & 66.29 & 68.06 & 65.92 \\
\cline { 2 - 7 } & MTPS & 74.14 & 74.74 & 71.32 & 76.11 & 72.51 \\
\hline \multirow{2}{*}{ System } & BS & 69.07 & 67.67 & 67.61 & 68.60 & 67.61 \\
\cline { 2 - 7 } & NBS & 73.48 & 70.66 & 70.08 & 74.94 & 69.69 \\
\hline
\end{tabular}

For the AQ category each student is divided into five criteria, ie very high, high, medium, low, and very low. High and very high criteria are included in the Climber group. The medium category includes the Champer group. While the AQ categories are low and very low including the Quitter group. The percentage distribution of AQ grouping students is generally in Table 9. 
Table 9

Percentage of category of students' AQ

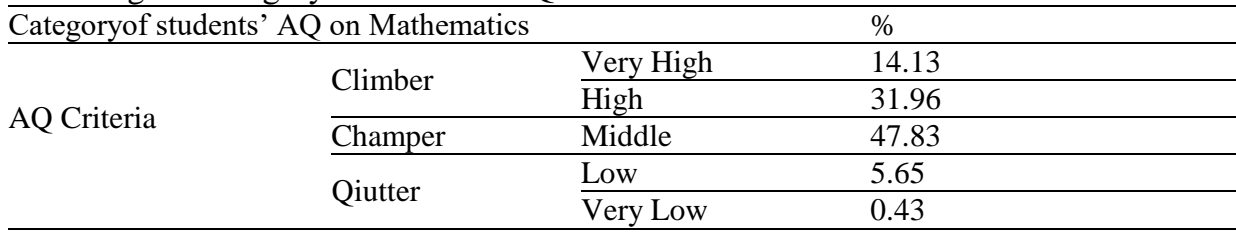

Distribution of students' AQ percentage was explained in Table 10.

Table 10

Distribution category percentage of students' AQ

\begin{tabular}{lllllll}
\hline \multirow{2}{*}{$\begin{array}{l}\text { Aspect/ } \\
\text { Category }\end{array}$} & Dimension & $\begin{array}{l}\text { Very High } \\
(\%)\end{array}$ & $\begin{array}{l}\text { High } \\
(\%)\end{array}$ & $\begin{array}{l}\text { Middle } \\
(\%)\end{array}$ & $\begin{array}{l}\text { Low } \\
(\%)\end{array}$ & $\begin{array}{l}\text { Very Low } \\
(\%)\end{array}$ \\
\hline \multirow{3}{*}{ Strategy } & CC & 9.581 & 28.743 & 55.689 & 5.389 & 0.599 \\
\cline { 2 - 7 } & MTPQ & 8.642 & 27.778 & 53.086 & 9.877 & 0.617 \\
\cline { 2 - 7 } & MTPS & 26.718 & 41.221 & 31.298 & 0.763 & 0.000 \\
\hline \multirow{2}{*}{ System } & BS & 9.615 & 29.167 & 55.128 & 5.449 & 0.641 \\
\cline { 2 - 7 } & NBS & 23.649 & 37.838 & 32.432 & 6.081 & 0.000 \\
\hline
\end{tabular}

From Table 8 and 9 above, it is envisaged that the highest percentage in the very high AQ group was obtained by students in the MTPS strategy group, students of NBS. For the "very low" AQ category, no student in the MTPS strategy group exists at this level, as well as for NBS students. But there are very low categorized students in BS schools.

\section{DISCUSSION}

Based on the results of the study, overall there are differences of Adversity Quotient students to mathematics in terms of differences in learning strategies. The test result proves high student AQ in the group of students who get MTPS strategy compared to the other two strategies, it is seen from the average of respective AQ MTPS, CC, MTPQ respectively $(98,73),(90,20),(89.39)$. Thus, the metacognitive strategy of think-aloud in cooperative pairs gives better influence to AQ than the other two strategies. This supports the study of Lioe et al. (2006) suggests that small group settings can elicit disclosure of students' words spontaneously and enable them to improve their ideas through critical testing. Thus, the process of thinking with metacognitive students in a pair more maximal so as to increase student awareness, confidence, and intuition. This reinforces Schoenfeld's (1987) view that the process of metacognition can give a belief to a person that a problem can be solved, he also has the intuition that the problems that arise can be solved with certain ideas and processes. It supports the students' ability to control themselves, thinking, and be able to keep reach in the learning of mathematics.

Furthermore, in terms of the school system, in the NBS school group, there is a difference of AQ students to mathematics. Similarly in the NBS school group, there is a difference in the student's AQ from each learning strategy. If viewed from the MTPS strategy, it can be concluded that the AQ of NBS is higher than the AQ of BS students. This can occur with a variety of factors, such as the difference between the school 
system of BS and NBS causing differences in learning time patterns, rest, also including the level of motivation to learn, the level of stress on students. The results of this study in line with the results of research Aminullah (2013) states that the mathematical anxiety of students in school students at boarding school, higher than junior high school students with characteristics instead of boarding school. In this case, NBS has the same characteristics with junior high school that is a school that is not a boarding school. With the anxiety of students in learning mathematics, giving influence either directly or indirectly in learning (Ahmad, 2016).

When viewed from the AQ indicator, all indicators are highest in this strategy group. All indicators on the MTPS strategy are categorized high, while in the other two strategies all indicators are moderately categorized. Thus the Think-aloud metacognitive learning strategy in pairs is more effective in improving students' self-control, students feel they can improve the situation, are able to limit the difficulty of not penetrating other aspects of their lives, and are able to survive through the difficulties experienced during the process of solving mathematical problems.

In MTPS learning, paired communication interaction is more active than the interaction is done in square and CC learning. Students have high self-confidence and selfconfidence as an aspect of a good level of Control, have high responsibility and focus as the Ownership and Reach implications, and have high fighting power, never give up in the face of any problems that are facing. Thus AQ students are better off using the MTPS learning strategy.

The results of this study support the results of previous research which states that the application of metacognitive teaching in cooperative learning settings can present the right conditions for students elaborating students' mathematical reasoning (Kramarski et al., 2002). In parallel, cooperative learning can increase students' thinking awareness (Blakey \& Spence, 1990). Thus, students 'awareness of difficulties and finding solutions in mathematics learning makes controlling, students' endurance to problems, not easily discouraged, and not stress arises as an aspect of AQ. This is in line with the results of Nurhayati and Fajrianti's research (2013), that a person with high achievement motivation, and Pangma et.al., (2009) research that a sense of responsibility, and highstress resistance will have a reciprocal effect on AQ students.

\section{CONCLUSIONS AND RECOMMENDATIONS}

From the previous discussion, it can be concluded that there are differences in Adversity Quotient (AQ) between students who follow the learning of MTPS, MTPQ, with Conventional Class (CC) both in terms of overall strategy and viewed from the school system. Furthermore, the strategy that gives the best influence to the student AQ is the MTPS strategy. Therefore, MTPS learning can be used as an alternative learning strategy in mathematics learning in improving students' AQ. Another conclusion is that there is an interaction effect between learning strategies (MTPS, MTPQ, and CC) and school systems (BS, NBS) on Adversity Quotient (AQ) students. Thus AQ students due to the effect of using learning strategies depend on the shape of the school system and vice versa. 
AQ students were higher in the non-boarding school (NBS) group than in the AQ of boarding school (BS) students. Student AQ indicators are high on control and reach aspects, while other indicators are categorized (origin, ownership, and endurance). In other words, the MTPS strategy can have more impact on the control and reach aspects of the student AQ than the other three aspects of AQ.

The grouping of students in the cooperative group needs to be considered by the researcher. This is so that the process of think-aloud can be maximal, run naturally. Student grouping should not only consider the academic aspects of the students, but also the activity of student communication. In addition, there needs to be a code used as a reminder to the students to keep talking in their group. The code can be used with a flag, or a specific image or symbol raised by the teacher to a think-aloud group.

This researcher uses the metacognitive think-aloud as a learning strategy in an effort to grow AQ students towards mathematics. There are many other metacognitive strategies that can be used in mathematics learning. Therefore, the metacognition aspect as a capability, and AQ as an approach can be studied further. Further research can be studied looking for other factors that affect student AQ, such as aspects of stress, student achievement motivation, and so forth both quantitatively and qualitatively.

\section{REFERENCES}

Abdurrahman, M. (1999). Pendidikan Bagi Anak Berkesulitan Belajar. Jakarta: Rineka Cipta

Ahmad, St Rahma Sami. (2016). Pengaruh Pobia, self-efficacy, adversity quotient dan motivasi belajar matematika siswa SMP. Jurnal Riset Pendidikan Matematika, 3(2), 259-272.

Ahmadi, Abu, dan Supriyono, W. 2004. Psikologi Belajar. Cetakan ke-2. Jakarta: Rineka Cipta.

Amir MZ, Zubaidah \& Wahyudin. (2016). Exploration of Metacognitive Ability at Elementary School Students in Learning Mathematics (Case Study in 1th Grade Students of Elementary School). Journal of Innovative Technology and Education, 1(3) 197-184.

Amir MZ, Zubaidah, dkk. (2017). Adversity Quotient in Mathematics Learning (Quantitative Study on Students Boarding School in Pekanbaru).International Journal on Emerging Mathematics Education, 1(2), 169-176.

Amir MZ, Zubaidah, dkk. (2017). Metacognition Think Aloud Strategies In Setting Cooperative Think-Pair-Share/Square to Develop Student's Math Problem Solving Ability (Comparative Study on Students of Madrasah Tsanawiyah Boarding/nonBoarding school in Pekanbaru). Advances in Social Science, Education and Humanities Research (ASSEHR), 57(1), 122-157.

Amir MZ, Zubaidah. (2017) Strategi Metakognitif Dalam Pembelajaran Matematika.Jurnal Penelitian dan Pembelajaran Matematika, 10(1), 60-67. 
Aminullah, M. A. (2013). Kecemasan antara Siswa SMP dan Santri Pondok Pesantren. Jurnal Ilmiah Psikologi Terapan, 1(2), 205-215

Blakey, E., \& Spence, S. (1990). Developing metacognition. Eric Reproduction Services No. ED327218. Retrieved from http://www.eric.ed.gov/PDFS/ED327218.pdf

Camp, B. W., Blom, G. E., Hebert, F., \& Van Doorninck, W. J. (1977). "Think Aloud": A program for developing self-control in young aggressive boys. Journal of Abnormal Child Psychology, 5(2), 157-169

Canivel, L. D. (2010). Principals' adversity Quotient: Styles, performance and practices. Retrieved from Peak Learning, Inc. website: http://www. peaklearning. com/documents/PEAK_GRI_canivel. pdf.

de Corte, E. (1996). Instructional psychology: Overview. In E. de Corte \& E. Weinert (Eds.), International encyclopedia of developmental and instructional psychology (pp. 33-43). Oxford: Elsevier Science. XX PP

Isna, N. L., dkk. (2013). Proses Berpikir Kreatif Siswa Kelas X Dalam Memecahkan Masalah Geometri Berdasarkan Tahapan Wallas Ditinjau Dari Adversity Quotient(Aq) Siswa. Jurnal Pendidikan Matematika Solusi, 1(1), 1-16

Kadir dan Nur. (2000). Pengajaran Langsung. Unesa Surabaya

Kramarski, B. Mevarech, Z.R., Arami, M. (2002). The Effects of Metacognitive Instruction on Solving Mathematical AuthenticTasks.Educational Studies in

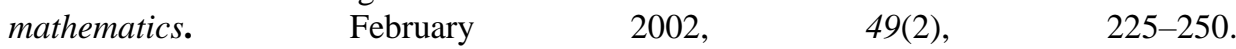
http://link.springer.com/article/10.1023/A:1016282811724

Leikin, Rozaand Orit Zaslavsky. (1999). Cooperative Learning In Mathematics. Source: The Mathematics Teacher, 92(3), 240-246

Lie, Anita, (2007). Cooperative Learning. Jakarta, Grasindo

Lioe, L.T., Fai, H. K., Hedberg, J.G.(2006). Thinker-Listener Pair Interactions to Develop Student's Metacognitive Strategies for Mathematical Problem Solving, Nanyang Technology University, Singapore. https://repository.nie.edu.sg/bitstream/10497/2927/1/CRP1_04JH_Conf05(ICMI)_Lioe HoHedberg.pdf

Wardiana, I. P. A., Wiarta, I. W., \& Zulaikha, S. (2014). Hubungan Antara Adversity Quotient (AQ) Dan Minat Belajar Dengan Prestasi Belajar Matematika Pada Siswa Kelas V SD di Kelurahan Pedungan. MIMBAR PGSD, 2(1).

Matore, Mohd Effendi Ewan Mohd; Ahmad Zamri Khairani\& Nordin Abd Razak. (2015). The Influence of AQ on the Academic Achievement among Malaysian Polytechnic Students. International Education Studies, 8(6), 69-74. DOI:10.5539/ies.v8n6p69 
Nurhayati dan Noram Fajrianti. (2013). Pengaruh Adversity Quotient (AQ) dan Motivasi Berprestasi terhadap Prestasi Belajar Matematika. Jurnal Formatif, 3(1), 7277.

Pangma, Rachapoom; Sombat Tayraukham, dan Sombat Tayraukham. (2009). Causal Factors Influencing Adversity Quotient of Twelfth Grade and Third-Year Vocational Students. Journal of Social Sciences, 5(4), 466-470

Papaleontiou-Louca, E. (2003). The concept and instruction of metacognition. Teacher Development,7(1), 9-30

Parvathy, Usha and Praseeda M. (2014). Relationship between Adversity Quotient and Academic Problems among Student Teachers. IOSR Journal Of Humanities And Social Science (IOSR-JHSS, 19(11), 23-26.

Phoolka, S.K. (2012) Adversity Quotient: A new paradigm in Management to explore. The International Journal Research adn Publication's. Research Journal of Sicial Scince and Management, 2(7), 109-117.

Sardiman, (2012). Interaksi \& Motivasi Belajar Mengajar, Jakarta: PT Rajagrafindo Persada

Schoenfeld, A. (1987). Metacognition. Learning and Mathematics [Online]. Tersedia: http://mathforum.org/ sarah/Discussion.Sessions/schoenfeld.html

Stoltz, Paul G. (2004). Adversity quotient mengubah hambatan menjadi peluang. Alih bahasa T. Hermaya. Jakarta: PT Gramedia Widiasarana Indonesia

Sudarman, (2011). Proses berpikir siswa quitter pada sekolah menengah Pertama dalam penyelesaikan masalah matematika. Edumatica, 1(2). DOI: https://doi.org/10.22437/edumatica.v1i02.181

Sudarman, (2012). Adversity Quotient Kajian Kemungkinan Pengintegrasiannya dalam Pembelajaran Matematika. AKSIOMA, 1(1). Retrieved From: https://garuda.ristekbrin.go.id/documents/detail/111506

US, Supardi. (2013). Pengaruh Adversity Quotient Terhadap Prestasi Belajar Matematika. Formatif, 3(1), 61-71.

Tint, S. S. \& Nyunt, E. E. (2015). Collaborative Learning With Think- Pair-Share Technique. Computer Applications: An International Journal (CAIJ), 2(1), 1-11. DOI : 10.5121/caij.2015.2101

Trianto (2007). Model-ModelPembelajaran Inovatif Berorientasi Konstruktivistik, Jakarta: Prestasi Pustaka

Yoong, W. K. (2012). Helping Your Students to Become Metacognitive in Mathematics: A Decade Later. http://intranet.moe.edu.sg/maths/Newsletter/FourthIssue/Vol2No5.html 
Zakiyah, N. dkk.(2010). Hubungan antara Penyesuaian Diri dengan Prokrastinasi Akademik Siswa Sekolah Berasrama SMP N 3 Peterongan Jombang. Jurnal Psikologi Undip, 8(2), 156-167. 